\title{
Climate change and increased risk for the insurance sector: a global perspective and an assessment for the Netherlands
}

\author{
W. J. W. Botzen · J. C. J. M. van den Bergh $\cdot$ L. M. Bouwer
}

Received: 6 October 2008/Accepted: 20 April 2009/Published online: 8 May 2009

(C) The Author(s) 2009. This article is published with open access at Springerlink.com

\begin{abstract}
Climate change is projected to increase the frequency and severity of extreme weather events. As a consequence, economic losses caused by natural catastrophes could increase significantly. This will have considerable consequences for the insurance sector. On the one hand, increased risk from weather extremes requires assessing expected changes in damage and including adequate climate change projections in risk management. On the other hand, climate change can also bring new business opportunities for insurers. This paper gives an overview of the consequences of climate change for the insurance sector and discusses several strategies to cope with and adapt to increased risks. The particular focus is on the Dutch insurance sector, as the Netherlands is extremely vulnerable to climate change, especially with regard to extreme precipitation and flooding. Current risk sharing arrangements for weather risks are examined while potential new business opportunities, adaptation strategies, and public-private partnerships are identified.
\end{abstract}

Keywords Adaptation - Business opportunities - Catastrophe losses · Climate change impacts - Insurance sector · Public-private partnerships · The Netherlands

W. J. W. Botzen $(\bowtie) \cdot$ L. M. Bouwer

Institute for Environmental Studies, Vrije Universiteit, Amsterdam, The Netherlands e-mail: wouter.botzen@ivm.vu.nl

L. M. Bouwer

e-mail: laurens.bouwer@ivm.vu.nl

J. C. J. M. van den Bergh

ICREA, Barcelona, Spain

J. C. J. M. van den Bergh

Department of Economics and Economic History, Institute of Environmental Science and Technology, Universitat Autònoma de Barcelona, Barcelona, Spain e-mail: jeroen.bergh@uab.es

J. C. J. M. van den Bergh

Faculty of Economics and Business Administration, Institute for Environmental Studies, Vrije Universiteit, Amsterdam, The Netherlands 


\section{Introduction}

Weather-related catastrophe losses have been significant in the last decade, posing considerable challenges to the insurance industry worldwide. For example, in the last decade (1996-2005) the United States experienced the second most damaging hurricane season ${ }^{1}$ of the past century in terms of damage that has been normalized for inflation and wealth. Only the decade 1926-1935 suffered higher damage costs due to hurricanes (Pielke et al. 2008). Weather-related losses in Europe have been considerable as well. The flooding in Germany during 2002 caused losses of about $€ 9.2$ billion (Munich Re 2002). ${ }^{2}$ England experienced two major flood events in the summer of 2007 caused by extreme precipitation. Overall economic losses amounted to about four billion dollars per event, of which three billion was insured. The extent of economic losses suffered highlights the vulnerability of modern societies to climate extremes.

It is projected by the Intergovernmental Panel on Climate Change (IPCC) that climate change may increase the frequency and severity of weather extremes, such as (extreme) precipitation, tropical cyclones, and heat waves in certain regions. The effects of climate change on other small-scale extreme weather phenomena, such as lightning and hailstorms, remain uncertain (IPCC 2007). The potential of global warming to increase vulnerability to weather extremes is especially relevant for the insurance sector (Vellinga et al. 2001). The insurance industry is the world's largest industry in terms of revenues and insurers bear a large portion of weather-related risks, such as damage caused by floods and storms (Mills 2007).

A study of five out of ten of the largest liability insurers and three additional insurers ${ }^{3}$ in the Netherlands concludes that climate change is not regarded as a worrisome issue (de Rooij and van den Bergh 2005). Insurers argue that adjustments of premiums and levels of coverage are sufficient to accommodate changes in loss patterns. Indeed, the flexible nature of the industry characterized by mostly short-term contracts, which allow for fairly quick adjustment of premiums, seems to assure its resilience against climate change. Nevertheless, the lack of concern may turn out problematic if it means that increased loss exposures are insufficiently and with considerable delay incorporated in premiums and risk management practices. Adjusting premiums based on experiences of past claims may insufficiently reflect changes in the probability of extreme weather events due to their low probability nature.

The relevance of weather risks for the insurance sector becomes evident by observing past trends in insured and other economic natural catastrophe losses. Data of past natural catastrophe losses collected by Munich Re (2006) indicate that increased global trends in losses can already be observed. The main factor behind this rise in losses has been societal change. Continued economic growth, economic development and population growth, notably in vulnerable regions (e.g., coastal zones), combined with rapid and extreme climate change is likely to accelerate and magnify the tempo and extent of damages. The influence of climate change on trends in catastrophe losses is likely to be profound since a large change in weather extremes can be expected due to a change in mean climate

\footnotetext{
${ }^{1}$ For instance, the hurricanes Katrina, Wilma, and Dennis that have hit the USA and nearby located countries in 2005 caused estimated economic losses of about 174 billion dollar, of which 66 billion was insured. Insured losses of hurricane Katrina alone are estimated to be 45 billion dollar (Swiss Re 2006).

${ }^{2}$ In total, the floods in Europe during August 2002 caused economic damages of about 15 billion dollar, of which 3.2 billion was insured. A few weeks later extreme precipitation in France caused estimated losses of 1.2 billion dollar, of which 0.4 billion was insured (Swiss Re 2003).

3 These additional companies are the primary insurers Euro Lloyd and SNS, and reinsurance broker Aon (de Rooij and van den Bergh 2005).
} 
conditions (Dlugolecki 2006). The best strategy for insurers seems to incorporate expected changes in probabilities of weather extremes in assessing exposure to, and pricing and management of, risk. Projected changes in probabilities of extreme weather events can be obtained from regional climate models, from which the Royal Dutch Meteorological Institute (KNMI) has developed climate scenarios for the Netherlands (van den Hurk et al. 2006). A clear need for adaptation measures exists to reduce risk exposure given the historical emissions of greenhouse gasses and their subsequent effect on radiative forcing in the future (Pielke et al. 2007). Moreover, societal developments such as increased economic development in vulnerable areas, e.g., coastal zones, necessitate the undertaking of risk reduction policies in order to guarantee insurability of weather risks. In addition to commonly used traditional measures to limit risks, such as increasing premiums and limiting coverage, the insurance sector could play an important role in stimulating and promoting climate change mitigation and adaptation policies (Mills 2007).

Climate change projections for the Netherlands mainly indicate an increase in risk of extreme weather events (van den Hurk et al. 2006). Nevertheless, the consequences of climate change for insurers are not only negative. For example, the probability of frost may decline in the future which could decrease claims on certain crop insurance policies. Climate change can further present new profitable business opportunities. Insurance demand for currently non-existing insurance markets can increase in the future when economic losses of weather risks increase (Botzen and van den Bergh 2009). However, problems with insurability of weather risks may hamper the development of markets, due to the correlated nature of these risks and the uncertainty associated with the likelihood and impact of extreme weather events (Kunreuther and Michel-Kerjan 2007). Because of these difficulties, recently, public-private partnerships have been proposed to insure catastrophe losses in the USA (e.g., Kunreuther 2006; Kunreuther and Pauly 2006) and flood risks in the Netherlands (Botzen and van den Bergh 2008). Such partnerships may also be promising solutions for meeting demand to compensate weather related damages that are currently not covered by private insurance, such as drought risk for the Dutch agriculture sector.

This paper will examine the current distribution of weather risks between the public and insurance sectors in the Netherlands and explores how these risks may be affected by climate change. The analysis will address a wide range of weather events, such as extreme precipitation and floods, windstorms, extreme drought, and hailstorms. Observed changes in climate and climate change projections for the Netherlands will be taken as a starting point. Furthermore, the consequences of climate change for the insurance sector are assessed and alternative arrangements are explored, while several strategies the insurance sector can adopt to deal with increasing risks are investigated.

The remainder of this paper is structured as follows. Sect. 2 highlights the relevance of climate change for the (global) insurance sector and provides insight into historical developments of catastrophe losses globally. Sect. 3 presents both observed and projected changes in climate for the Netherlands. This serves as the basis for Sect. 4, which examines the effects of climate change for current risk sharing arrangements in the Netherlands. Subsequently, Sect. 5 identifies several strategies for insurers and the government to deal with increased risks. Finally, Sect. 6 concludes.

\section{The relevance of climate change for the insurance sector worldwide}

Some of the projected changes by IPCC in extreme weather events that have been discussed in the previous section can already be observed. Research confirms that climate 
Table 1 Natural catastrophe losses per decade between 1950 and 2005 in US\$ bn. (2005 values)

\begin{tabular}{lcccccc}
\hline Decade & $1950-1959$ & $1960-1969$ & $1970-1979$ & $1980-1989$ & $1990-1999$ & $1996-2005$ \\
\hline Number of events & 21 & 27 & 47 & 63 & 91 & 57 \\
Economic losses $(L)$ & 48.1 & 87.5 & 151.7 & 247 & 728.8 & 575.2 \\
Insured losses $(I)$ & 1.6 & 7.1 & 14.6 & 29.9 & 137.7 & 176 \\
L/I ratio & 30.06 & 12.32 & 10.39 & 8.26 & 5.29 & 3.27 \\
\hline
\end{tabular}

Source: Adapted from Munich Re (2006)

change is, at least partly, associated with an increased frequency or intensity of certain weather extremes that has been observed in the last decades, such as heat waves, extreme precipitation, and tropical cyclones (IPCC 2007).

Weather-related loss patterns indicate an increased importance of natural disasters for the insurance sector. Global inflation-adjusted insured and other economic losses of natural catastrophes as well as the frequency of events between 1950 and 2005 have increased considerably, as shown in Table 1. It is relevant for insurance companies that insured losses increased rapidly as well, which is partly due to higher insurance penetration. This is reflected by the $L / I$ ratio, where $L$ denotes economic loss and $I$ insured loss. This ratio has decreased from 30 in the 1950 s to about 3 in the period 1996-2005, because of the development of insurance markets worldwide. The development of the $L / I$ ratio of natural disaster losses signifies the increased importance of extreme weather events for insurers. The proportion of losses caused by weather-related events in total catastrophe losses is significant. For example, storms and floods account for 58\% of economic losses and $80 \%$ of insured losses between 1950 and 2004 (Munich Re 2005). Growth trends in losses as a result of non-weather related events have been rather constant over the past three decades (Vellinga et al. 2001; Swiss Re 2005). This could mean that weather extremes have become more frequent and severe, or that vulnerabilities to weather and non-weather types of hazards have evolved differently over time.

Empirical evidence suggests that climate change may have contributed to the increased losses caused by natural disasters, due to an increased frequency and intensity of extreme weather events (Vellinga et al. 2001; Epstein and McCarty 2004; Mills 2005). However, caution is warranted, as considerable uncertainty remains concerning the influence of past climate change on the recent growth in losses (Changnon et al. 2000; Pielke et al. 2005). It has been shown that the rise in losses around the world is mainly due to socioeconomic factors (Changnon 2003; Bouwer et al. 2007; Miller et al. 2008; Crompton and McAneney 2008). A major part of the trend is caused by hurricane damage in the USA, which do not exhibit an upward trend after normalization for societal change, in particular, changes in wealth or assets (Pielke 2005; Pielke et al. 2008). Socioeconomic factors that caused increased losses are population growth, growth in single person households, increasing wealth, environmental degradation, industrialization in more vulnerable areas (e.g., flood plains and coastal areas), increased vulnerability of modern societies and technology, and increased concentration of population and economic values (Berz 1999; Hoff et al. 2003). In addition, increased insurance coverage and changing attitudes toward compensation have resulted in a rise in the reporting of losses (Vellinga et al. 2001).

The effects of disaster risk reduction may potentially limit the influence of climatic factors on loss trends. Examples of risk reduction are increased coastal and river protection, improved building codes, improved weather forecasts, early warning systems, and 
improved disaster preparedness, response and recovery. In general, it is difficult to determine the independent role of climate change in the increase in losses reported due to the low probability nature of extreme events, the relatively short time span of loss records and the various societal factors that influence disaster loss records.

In the past, the major cause of increased catastrophe losses have been socioeconomic developments, such as increases in wealth and vulnerability. In the future, a combination of societal change and climate change is likely to result in a considerable increase in insured disaster losses. Bouwer et al. (2007) have indicated that loss potentials of the 10 largest cities of the world are projected to increase between 22 and $88 \%$ by 2015 due to socioeconomic developments only. In addition to societal change, insurers are expected to suffer from changes in location, frequencies and intensities of catastrophic events, for example major storms, as well as ordinary (smaller) weather events, such as local precipitation (Mills et al. 2002). The result will be an increasing average loss burden and larger yearly fluctuations in losses.

Premium income may lag behind the development of claims if the changing risks due to climate change are not properly accounted for in calculating premiums. Merely adjusting premiums on past experience is unlikely to fully reflect changes in risk in the face of lowprobability high-impact events (Tucker 1997). This can result in declining reserves and profitability of insurers. However, increased diversification and firm size, integration of insurance with other financial services, the development of improved financial instruments to transfer risk, and the flexible nature of the industry with short-term contracts contribute to overall resilience of the sector against climate change. Adaptation of the insurance industry to risks that change gradually will be less difficult and costly than adaptation to rapidly changing risks.

We note that the effects of socioeconomic developments and climate change on natural disaster damage are unequally distributed around the world (IHDP 2007). Climate change is expected to have larger economic consequences for developing countries (e.g., Tol 2002a, b; Stern 2007), mainly because their adaptive capacity is lower and they can spend fewer resources on an effective adaptation policy. For example, coastal cities like Mumbai and Rio the Janeiro in developing countries are less protected against sea level rise than cities like Rotterdam in the Netherlands (de Sherbinin et al. 2007). Moreover, socioeconomic effects that augment natural disaster damage, such as increased urbanization, are expected to be more profound in the developing world. As an illustration, 95\% of urban growth in the next two decades is expected to occur in developing countries (SanchezRodriguez et al. 2007). Often poor households are more at risk of natural disaster than richer households in developing countries, for example, because they live closer to main rivers (e.g., Brouwer et al. 2007). Poor households in developing countries commonly lack access to insurance markets so that most damage of weather risks is not carried by the insurance sector (Hoff et al. 2005). In contrast, insurance penetration is high in most developed countries so that they cover a large part of the risk posed by climate change. The effects of climate change for insurers and possible strategies to cope with these risks will be discussed in a case study of the Netherlands in the subsequent sections.

\section{Observed climate change and projections for the Netherlands}

This section outlines the observed and projected changes in climate for the Netherlands. The findings and projections discussed are based on studies of the Royal Dutch Meteorological Institute (Verbeek 2003; van den Hurk et al. 2006). In general, climate change in 
Table 2 Projected climate change for the Netherlands in 2050

\begin{tabular}{|c|c|c|c|c|}
\hline & \multicolumn{4}{|l|}{ Scenario } \\
\hline & Moderate & Moderate+ & Warm & Warm+ \\
\hline Global temperature rise & $+1^{\circ} \mathrm{C}$ & $+1^{\circ} \mathrm{C}$ & $+2^{\circ} \mathrm{C}$ & $+2^{\circ} \mathrm{C}$ \\
\hline Change in atmospheric circulation & No & Yes & No & Yes \\
\hline \multicolumn{5}{|l|}{ Winter } \\
\hline Mean temperature & $+0.9^{\circ} \mathrm{C}$ & $+1.1^{\circ} \mathrm{C}$ & $+1.8^{\circ} \mathrm{C}$ & $+2.3^{\circ} \mathrm{C}$ \\
\hline Yearly coldest day & $+1^{\circ} \mathrm{C}$ & $+1.5^{\circ} \mathrm{C}$ & $+2.1^{\circ} \mathrm{C}$ & $+2.9^{\circ} \mathrm{C}$ \\
\hline Mean precipitation & $+3.6 \%$ & $+7.0 \%$ & $+7.3 \%$ & $+14.2 \%$ \\
\hline Wet day frequency & $+0.1 \%$ & $+0.9 \%$ & $+0.2 \%$ & $+1.9 \%$ \\
\hline \multicolumn{5}{|l|}{ 10-year return level 10-day } \\
\hline Precipitation sum & $+4 \%$ & $+6 \%$ & $+8 \%$ & $+12 \%$ \\
\hline \multicolumn{5}{|c|}{ Maximum average daily wind speed } \\
\hline Per year & $0 \%$ & $+2 \%$ & $-1 \%$ & $+4 \%$ \\
\hline \multicolumn{5}{|l|}{ Summer } \\
\hline Mean temperature & $+0.9^{\circ} \mathrm{C}$ & $+1.4^{\circ} \mathrm{C}$ & $+1.7^{\circ} \mathrm{C}$ & $+2.8^{\circ} \mathrm{C}$ \\
\hline Yearly warmest day & $+1.0^{\circ} \mathrm{C}$ & $+1.9^{\circ} \mathrm{C}$ & $+2.1^{\circ} \mathrm{C}$ & $+3.8^{\circ} \mathrm{C}$ \\
\hline Mean precipitation & $+2.8 \%$ & $-9.5 \%$ & $+5.5 \%$ & $-19 \%$ \\
\hline Wet day frequency & $-1.6 \%$ & $-9.6 \%$ & $-3.3 \%$ & $-19.3 \%$ \\
\hline \multicolumn{5}{|l|}{ 10-year return level 10-day } \\
\hline Precipitation sum & $+13 \%$ & $+5 \%$ & $+27 \%$ & $+10 \%$ \\
\hline Potential evaporation & $+3.4 \%$ & $+7.6 \%$ & $+6.8 \%$ & $+15.2 \%$ \\
\hline Absolute sea level rise & $12-25 \mathrm{~cm}$ & $15-25 \mathrm{~cm}$ & $20-35 \mathrm{~cm}$ & $20-35 \mathrm{~cm}$ \\
\hline
\end{tabular}

Source: van den Hurk et al. (2006)

the Netherlands is in accordance with global climate change. Mean temperature in the Netherlands has risen with $1.2^{\circ} \mathrm{C}$ from 1900 on, which is slightly higher than the observed rise in global temperature. The increase in temperature has been associated with a strong increase in the number of extremely warm days and a moderate decrease in the number of extremely cold days. ${ }^{4}$ All of the ten warmest days since 1900 took place after 1988 (van den Hurk et al. 2006). Yearly precipitation in the Netherlands increased by $18 \%$ from 1906 on, which is mainly caused by increased precipitation in the winter, spring and autumn. Furthermore, extreme precipitation increased considerably during winter. The highest "10-day precipitation sum" per winter has increased by $29 \%$ since 1906 . An increase in the frequency of storms has not been measured. In contrast, the number of storms gradually decreased from 1962 on (van den Hurk et al. 2006).

Climate change projections for the Netherlands in 2050 relative to 1990 are shown in Table 2. ${ }^{5}$ Projections are made for four scenarios including a moderate and a warm

\footnotetext{
4 A specific day is defined to be extremely cold (warm) when the temperature on that day was lower (higher) during only $10 \%$ of the days between 1961 and 1990 (Verbeek 2003).

5 A recent study by the "Delta Committee" in the Netherlands also presents climate change scenarios for longer time horizons, namely up to 2100 and 2200 (see http://www.deltacomissie.com in Dutch). These projections are not discussed here, since they provide an upper estimate of extreme climate change, and because the short term projections up to 2050 are more relevant for the insurance sector that has a short planning horizon.
} 
scenario in which global temperature increases by 1 and $2^{\circ} \mathrm{C}$, respectively, and corresponding "plus" scenarios in which atmospheric circulation changes in addition to the temperature change. Westerly circulation is stronger in winter and easterly circulation is stronger in summer in these plus scenarios.

Mean temperature is expected to increase between $0.9^{\circ} \mathrm{C}$ in the moderate scenario and $2.3^{\circ} \mathrm{C}$ in the warm plus scenario by 2050 . This increases the frequency of very warm summers, while the frequency of very cold winters decreases. Average precipitation in wintertime is expected to increase between 3.6 and 14.2\%. The expected increase in summer precipitation is smaller in the moderate and warm scenarios with 2.8 and $5.5 \%$ by 2050, respectively. Average summer precipitation is even projected to decrease by 9.5 and $19 \%$ in the moderate plus and warm plus scenarios. Extreme precipitation is projected to increase considerably both in the winter and the summer. In contrast, the frequency of wet days decreases during the summer. Evaporation in the summer is also expected to increase significantly, especially when circulation patterns change, which increases the probability of droughts. Projected changes in the maximum average daily wind speeds per year are small. The strength of the heaviest storms (that occur less than once a year) could increase, even though van den Hurk et al. (2006, p. 73; and references therein) indicate that this is still very uncertain. Sea level is projected to rise between 15 and $25 \mathrm{~cm}$ for $1^{\circ} \mathrm{C}$ of global warming and between 20 and $35 \mathrm{~cm}$ for $2^{\circ} \mathrm{C}$ of global warming by 2050 . The projected changes in climate shown in Table 2 can be expected to have a considerable impact on the Dutch economy and society as well as the insurance industry, which will be examined in the next section. In particular, these climate change projections indicate an increase in risk for extreme precipitation, flooding and drought spells.

\section{Risk sharing arrangements of weather risks in the Netherlands}

This section examines the main impacts of climate change on insured and uninsured weather-related losses in the Netherlands. The purpose is to identify which major weather risks are currently carried by the insurance or public sector, or households and businesses. Moreover, it will be examined how existing risk sharing arrangements may be adapted in response to climate change. This requires analyzing the economic consequences of the climate change projections discussed in Sect. 3, which can subsequently be related to specific risk sharing arrangements that are currently available in the Netherlands or that might be developed in response to changing risk. Climate change impacts will be discussed for extreme precipitation and flooding, windstorms, extreme drought, and hailstorms. The main focus is on monetary (property) losses caused by weather events. Although reference will be made to effects of extreme weather on health and life insurance, the overall impact of climate change on death rates due to extreme weather is expected to be limited in a developed country like the Netherlands. Globally, mortality rates due to extreme weather events have decreased considerably over the last century (IFRC 2003; Goklany 2007), which indicates that societies have been able to adapt to increased health risks caused by more extreme weather, for example, by means of improved medical care (Goklany 2007). Evidently, human adaptation to climate change may also limit the damage caused by future natural catastrophes. Several adaptation strategies are provided that are specific to the weather risk discussed in this section and general strategies that can be undertaken by the insurance sector will be examined in Sect. 5 . 


\subsection{Extreme precipitation and flooding}

Especially relevant for low-lying countries such as the Netherlands, are the economic consequences of increased (extreme) precipitation, peak discharges of rivers and sea level rise. We need to make a distinction between the risks of flooding and extreme precipitation, since different risk sharing arrangements exist for these risks. Flood damage is defined as damage caused by the failure of primary dikes or dams that protect areas from flooding of main rivers or lakes, which may be caused by extremely high water discharges, extreme drought that weakens dikes, or technical and human failures. Moreover, the potentially largest flood damage can be caused by flooding from the sea due to failures of coastal defenses during a storm surge. Extreme precipitation damage is defined as heavy local rainfall that can cause direct damage to property and crops, or result in an overflowing of secondary waterworks ${ }^{6}$ at smaller rivers. Extreme precipitation can also inundate low-lying polders.

Climate change is expected to increase the risk of river flooding in the Netherlands, which can cause significant economic costs, as shown by the river floods in 1993 and 1995. The total damage of these floods amounted to approximately $€ 115$ and $€ 65$ million, respectively (Kok and Barendregt 2004). The Netherlands is very vulnerable to flooding, since about $70 \%$ of properties lie below sea or river water levels (Kok et al. 2002). Private flood insurance offered by insurance companies is not generally available since the major storm surge in 1953, implying that flood damage has to be paid by the private sector and the government. An exception is flood damage to cars, which is covered by motor hull insurance. Estimated losses for car insurers during the 1993 flood in the Netherlands were less than $€ 0.5$ million (van Schoubroeck 1997).

Apart from increased flood risks due to precipitation, sea level rise may increase the intensity of storm surges, which are the main causes of sea floods in the Netherlands. Storm surges occur when water is pushed toward the shore by the force of strong winds. The probability of storm surges may increase if rises in sea level are very extreme. This may cause increased coastal protection to be insufficient. Flood risks are even higher in case where climate change also leads to higher wind speeds on the North Sea (Bouwer and Vellinga 2007). The impact of storm surges in the Netherlands can be catastrophic, both in terms of expected economic losses, which could be in the order of $€ 100$ billion (Kok et al. 2002), and potential loss of life in the order of hundreds to thousands (Jonkman and Cappendijk 2006).

Flood damage can be partly compensated by the government via the Calamities and Compensation Act (WTS), which is in force since 1998. An exception to this is damage caused by saltwater floods. The cabinet needs to give a separate approval to compensate damage of saltwater floods (Nielen-Kiezebrink et al. 2005). Recently, the government decided to stimulate private flood insurance, for which purpose a "Task Force" consisting of insurance companies and officials from several ministries has been established.

The ad hoc arrangement via the WTS is undesirable, because eligibility for compensation is uncertain and incentives to limit losses for households are minimal. ${ }^{7}$ Moreover,

\footnotetext{
${ }^{6}$ Secondary waterworks are dikes or dams located within an area that is surrounded by primary waterworks. Secondary waterworks provide protection against smaller rivers or lakes whose water levels can be regulated by the government via water management practices. In contrast, primary waterworks provide protection against flooding from main rivers, lakes or the sea whose water levels are difficult or impossible to regulate.

7 Insurance arrangements may stimulate the undertaking of damage reducing measures at the policyholder level (Botzen et al. 2009a). Such measures are effective in reducing flood damage near rivers, but may be infeasible in certain very low-lying polders.
} 
Fig. 1 A multi-layered insurance program

\begin{tabular}{|l|c|}
\hline Layer 3 & Government \\
\hline Layer 2 & Capital markets \\
& $\begin{array}{c}\text { Reinsurance companies } \\
\text { Primary insurance companies }\end{array}$ \\
\hline Layer 1 & Households and companies \\
\hline
\end{tabular}

projected increases in relief payments due to climate change may cause considerable pressure on public budgets. The advantages and difficulties with introducing insurance against damage from extreme weather events and flood insurance in the Netherlands in particular have been discussed extensively by Botzen and van den Bergh (2008) and therefore need not be repeated here. They propose a public-private partnership in the form of a multi-layered insurance arrangement for flood damage, as shown in Fig. 1. The bottom layer of small losses is paid by households and companies. The private insurance sectors cover the middle layer and hedge risks on capital markets while the top layer of large losses is covered by the government to overcome problems of insurability of highly correlated flood risks.

Damages resulting from extreme local precipitation can be considerable as well, even in the absence of a flooding event. For example, extreme precipitation events in 1998 caused damage of approximately $€ 408$ million, of which $80 \%$ was crop damage. The government compensated about $€ 280$ million, mainly via the Calamities and Compensation Act (WTS). Only $€ 27$ million of total damage was insured (Kok and Barendregt 2004). A large proportion of the damage was neither covered by private insurance nor compensated by the government and was, therefore, carried by households and businesses. In response to these severe precipitation events, the government urged to increase the insurability of damage resulting from extreme precipitation, in order to reduce future government relief payments (Kok and Barendregt 2004). In 2000 the Dutch Association of Insurers has advised its members to include coverage for damage caused by local extreme precipitation in building, home furniture, and inventory (company assets) insurance.

Currently, insurance against property damage that results from severe precipitation is readily available for households in the Netherlands. About $40 \%$ of the insurance companies that offer building and home furniture insurance to households cover damage resulting from severe local precipitation. In contrast, only $11 \%$ of the insurance companies that offer inventory, assets, and building insurance to companies cover this damage (Heerkens 2003). ${ }^{8}$ The definition of local extreme precipitation that the Dutch Association of Insurers suggested to include in insurance policies is precipitation near the location where damage has been caused of at least $40 \mathrm{~mm}$ in $24 \mathrm{~h}, 53 \mathrm{~mm}$ in $48 \mathrm{~h}$, and $67 \mathrm{~mm}$ in $72 \mathrm{~h}$. The current return period of more rainfall than $40 \mathrm{~mm}$ in $24 \mathrm{~h}$ is about 3 years (Wijngaard et al. 2005). The Royal Dutch Meteorological Institute (KNMI) has estimated that climate change may increase this return period to once in 2 or 1.5 years by 2050 , depending on the climate change scenario (Groen 2007). From this can be derived that a rough estimate of an increase in the frequency of insurance claims for extreme precipitation damage could be as high as a factor 2 . This is likely to have a considerable impact on insured losses. As an illustration, in 2003 insurance companies paid $\sim € 175$ million because of precipitation

\footnotetext{
8 This includes damage that results from overflowing of waterworks and direct rainfall on buildings, caused by severe local precipitation. It also covers damage that results from severe local precipitation in the farther neighborhood of the building that enters the building due to overpressure of waterworks. Exceptions are damage that results from flooding of primary waterworks, canals and storm surges, as well as damage caused by rising groundwater.
} 
damage (Kok 2006). Suppose that damage in that year is representative of an average year. In case if climate change increases the frequency of claims by a factor of 2 , then future insurance losses may be estimated as $€ 350$ yearly. It is assumed that losses increase linearly with precipitation intensity. This may, however, be a conservative estimate, if a rise in frequency and severity of precipitation would increase damages in a nonlinear way.

Crop damage caused by severe precipitation can be insured from 2004 onwards by the insurance company Agriver in the form of a public-private partnership. This insurance consists of a mutual fund that is financed by premium contributions by its policyholders. Policyholders can be obliged to increase their contributions to the fund up to six times their normal premium if yearly payouts exceed collected premiums. The government supports this insurance by doubling premium contributions up to $€ 50$ million per year in case severe damages arise that are larger than the capacity of the fund. A considerable part of the damage has to be paid by the agricultural sector, because the deductible is $25 \%$ of total insured damage. A similar type of insurance arrangement with a possibility for a lower deductible of $15 \%$ has been offered by the insurer Aquapol since 2005.

The policy conditions of crop insurance against extreme precipitation are more restrictive than for property insurance stated before. Damage will only be paid in case rainfall is more than $75 \mathrm{~mm}$ in less than $24 \mathrm{~h}$, more than $100 \mathrm{~mm}$ in less than $48 \mathrm{~h}$ or more than $150 \mathrm{~mm}$ in $96 \mathrm{~h}$. The current return period of more rainfall than $75 \mathrm{~mm}$ in $24 \mathrm{~h}$ is once in 70 years. This return period is projected to increase in between once in 20 years and once in 50 years due to climate change by the year 2050 (Groen 2007).

The extreme precipitation event in the South West of the Netherlands in 1998 may be exemplatory to illustrate the effects of climate change on crop insurance claims. The government compensated about $€ 140$ million of the damage suffered, of which approximately $€ 110$ million (80\%) was crop damage (Kok and Barendregt 2004). Damage was only compensated in areas where rainfall was more than $100 \mathrm{~mm}$ per $48 \mathrm{~h}$, which is more restrictive than the current crop insurance policy. If we suppose that this damage is representative for an event that triggers the crop insurance policy, then under current climate conditions the yearly expected loss of such an event is approximately $€ 1.6$ million. ${ }^{9}$ Climate change increases this yearly expected loss between $€ 2.2$ million up to $€ 5.5$ million in 2050, depending on the climate change scenario. Expected claims will be larger when more extreme precipitation increases damage nonlinearly.

Several adaptation measures can be undertaken to partly limit the rise in risks of extreme precipitation. Improved water management could reduce the damage that results from more extreme precipitation. For example, measures that are being considered are to increase capacity to store precipitation water, increase pumping capacity in low-lying areas and improve discharge possibilities of precipitation water via rivers (Aerts et al. 2008). Such measures only limit damage partially because damage caused by the direct impact of extreme rainfall is not prevented. Agricultural crop damage in particular may be limited by improving water drainage systems of farmers or shifting production to less vulnerable crop types and cultivation modes. Insurers could play a role in stimulating the undertaking of such damage mitigation measures via requirements in policy regulations or by providing discounts to farmers who invest in drainage systems. However, it is noted that in general, economic and societal developments are likely to be more important factors driving crop

\footnotetext{
9 This is computed by dividing the loss of $€ 110$ million by the return period of 70 years. This calculation is based on damage due to a single event instead of a yearly loss amount that was used in the previous computation of future claims on home insurance policies. This is done because crop insurance policies only pay out under more extreme rainfall than home insurance policies.
} 
choice and production modes than climate change (Netherlands Environmental Assessment Agency 2005).

Changes in precipitation may further affect road safety and related insurance claims of motor vehicle insurers. Koetse and Rietveld (2009) indicate, however, that the impact of changes in precipitation on road safety in the Netherlands is ambiguous. In the summer, the frequency of wet days is expected to decrease, while extreme precipitation is expected to increase. The combination of these effects has uncertain impacts on accident rates. During winter, both, the frequency of wet days and extreme precipitation are expected to increase, which may increase the risk of accidents. However, traffic is generally slower during precipitation, which may decrease the damage of an accident once it occurs. Further research is required to assess the influence of the combination of these effects on accident frequency and severity, before impacts on motor vehicle insurers can be estimated.

\subsection{Windstorms}

The Netherlands is susceptible to windstorms, especially during the winter. Past experience with windstorms indicates that storms can inflict considerable damage on properties. For example, the major windstorm Daria in 1990 caused estimated damages of $€ 1.2$ billion, which equals about $0.5 \%$ of the Dutch GDP at that time. Approximately $€ 0.7$ billion or $60 \%$ of this total damage was covered by insurance companies, which represents claims from damage on cars, private houses, businesses, as well as industrial and commercial buildings (Munich Re 1993). The insurance coverage of storm damage on property is nearly universal in the Netherlands. Only government properties are not insured. Therefore, the effects of climate change on wind speeds and storm frequencies are very relevant for Dutch insurers.

The climate change projections for maximum wind speed shown in Table 2 indicate that considerable uncertainty exists about the effects of global warming on the severity of windstorms. Maximum average daily wind speeds per year are expected to remain the same in the "moderate" and decrease in de "warm" scenario, while they are expected to increase by 2 and $4 \%$ in the "moderate plus" and "warm plus" scenarios. This increase in wind speeds in the plus scenarios seems minor. However, a small change in peak wind speeds can have considerable consequences for damage. This is the case because the relation between wind speed and damage is exponential for increases in wind speed between 1 and 10\%. In particular, Dorland et al. (1999) have estimated that a $2 \%$ increase in daily peak wind speed and scenarios of population and economic growth by the year 2015 may lead to 50\% more storm damage. This is based on using a geographical and statistical storm model for the Netherlands. ${ }^{10}$ Of this $50 \%$ additional damage, only $20 \%$ is due to population and economic growth, meaning that the change in climate is more important. Therefore, the effects of changes in wind speeds in the 'plus scenarios' of climate change projections on insurance losses could be substantial, if daily peak wind speeds increase as rapidly as the projected maximum average daily wind speeds per year. Further research on changes in atmospheric circulation in the Netherlands is needed before any conclusive statements about the likelihood of the plus scenarios and corresponding effects on insured windstorm losses can be made. ${ }^{11}$

\footnotetext{
${ }^{10}$ A simpler model that is based on national average data indicates that damage could even increase by $80 \%$ when peak wind speeds increase by $2 \%$ (Dorland et al. 1999).

11 The KNMI climate change scenarios comprise daily mean wind speeds. Further research is needed to obtain insight into prolonged or sustained wind speeds (van den Hurk et al. 2006).
} 


\subsection{Extreme drought}

Hot summers and periods of extreme drought are likely to become more common, as a result of global warming. The shortage of rainfall experienced in the moderately dry summer of 2003 in the Netherlands currently occurs once in every 10 years, while it is expected to occur every 6-8 years in 2050 (Versteeg et al. 2005). Water shortages can result in increased costs, reduced production and poor product quality. Impacts can be significant especially for the agricultural sector. Crop failure occurs when summers are extremely warm. In addition, crops will be damaged when farmers do not have sufficient access to water supplies for irrigation during periods of extreme drought. For example, the 2003 heat wave in Europe threatened Dutch agriculture in the low-lying delta due to increased salinity, which makes water unsuitable for irrigation purposes. Problems with salinity can become more severe in the future in the Western part of the Netherlands, due to sea level rise and land subsidence (Versteeg et al. 2005). Average long-term drought damage for the agricultural sector in the Netherlands is estimated to be $€ 150$ million per year and $€ 1.8$ billion in extremely dry years that occur every 90 years (RIZA et al. 2005). ${ }^{12}$ Currently, there is no insurance for farmers against crop damage resulting from drought, implying that these costs are born by the agricultural sector.

A recent study examines the possibilities of introducing insurance with coverage against extreme drought damage bundled with other weather risk for the agricultural sector in the Netherlands (van der Meulen et al. 2006; van der Meer et al. 2007). Based on a stakeholder analysis of representatives of the agricultural sector and insurers it concludes that these parties are positive about introducing a broad weather insurance, provided that this is financially backed up by the government. Insurance of drought risks is difficult in a purely private market due to a lack of statistical data to estimate loss distributions and the correlated nature of the risk. Moreover, a large deductible will be necessary to avoid problems of moral hazard. The government may play a role as a reinsurer of extremely large damages so that premiums are not too high, and a market can be established. A public-private partnership as currently exists in insuring crop damage caused by rainfall, or as has been proposed to insure flood damage seems promising for insuring agricultural losses caused by extreme droughts. Demand by the agricultural sector for such an arrangement is likely to increase in the future if climate change increases the frequency and intensity of drought spells.

An insurance coverage against extreme drought damage may be beneficial for economic stability broadly if it ensures continuity of individual farmers after heat spells and contributes to overall resilience of the agricultural sector against climate change by covering potentially catastrophic damage. In addition to introducing crop insurance against drought, other measures could be undertaken that foster adaptation of the agriculture sector to increased summer drought risk. For example, water storage during wet periods may be improved by creating new freshwater basins so that more irrigation water is available during dry spells. Moreover, farmers near the coast may shift to growing crop types that are

\footnotetext{
12 Decreased revenues because of drought are estimated to be on average $€ 675$ million per year (using 30 years of data). These losses are calculated by subtracting actual revenues from potential revenues obtainable in a situation with optimal circumstances. However, not all losses are perceived as damage. Reductions in revenues during years with average losses are regarded as being normal by the agricultural sector. Therefore, it is better to define damage as the excess reduction in revenues relative to an average situation. Using this definition, long-term average damage amounts to $€ 150$ million per year. This damage is adjusted for positive effects of warm summers on crop yields (RIZA et al. 2005).
} 
less susceptible to salinity of irrigation water, even though market developments are likely to be the main driving forces behind choices of cultivated crops (Stuyt et al. 2006).

Apart from effects on agriculture, periods of drought also have a considerable impact on the industrial, energy and shipping sectors (Versteeg et al. 2005). Less rain and increased evaporation decreases the supply of water available for cooling and shipping. Decreased availability of cooling water limits capacity for generating electricity and industrial production. Furthermore, increased salinity of water and higher water temperatures during drought periods decreases the quality of cooling water.

Ships on the major transport route Rotterdam-Germany-Basle cannot be fully loaded when discharges of the Rhine drop below 1,000-1,200 $\mathrm{m}^{3} / \mathrm{s}$, which increases transport costs. The costs of the 2003 drought for the inland waterway transport sector have been estimated as $€ 111$ million (RIZA et al. 2005), or about 11.1 million expected damage per year with a return period of once in 10 years under the current climate. ${ }^{13}$ Climate change is likely to increase the average number of days per year that the Rhine discharge at Lobith is below $1,000 \mathrm{~m}^{3} / \mathrm{s}$ from 19 under present conditions to 26 till 34 days in 2050 (Middelkoop et al. 2001). As a result, future transportation costs could rise and the profitability of shipping companies may decrease in case increased costs are not fully passed on into higher prices, or risks are not fully covered through contract design. Costs are mainly passed on through higher prices, which may be undesirable for clients of shipping companies if such costs increases occur commonly in the future due to climate change. At this moment the risks of drought are carried by these sectors themselves and insurance products are absent. It may be relevant for insurance companies to examine if profitable insurance products can be designed to hedge these losses in extremely dry periods, especially because other adaptation options are limited.

Insurance companies already face some risks of increased drought under current arrangements. An adverse effect of drought is increased fire risk. The probability of fire damage to residences and company buildings including home furniture and machinery is higher in dry periods, which can increase insurance claims. The probability of wildfires increases during periods of drought, resulting in more forest and heath fires, as happened in the Dutch national park "De Veluwe" during extreme drought in 1976. Such fires potentially damage (nearby located) property. Heat waves can further result in increased daily mortality and morbidity. For example, the 2003 heat wave in the Netherlands has been estimated to cause approximately 500 deaths due to heat stress, mostly among elderly people (Kabat et al. 2005). It is complicated to assess the impacts of increased illness on health insurance claims and mortality on life insurance claims caused by climate change compared with effects of climate change on property claims, due to difficulties in measuring their independent effects on insurance claims.

\subsection{Hailstorms}

Considerable uncertainty exists about the influence of climate change on the frequency and intensity of small-scale weather phenomena, such as hailstorms, and there are insufficient studies to assess historical changes (IPCC 2007, p. 315). The possible consequences of climate change on hailstorm damage are, nevertheless, very relevant for insurers in the Netherlands, since such events are very common and hailstorm damage is mostly covered by insurance policies. Hailstorms can inflict damage on, for example, buildings, vehicles,

13 Jonkeren et al. (2007) estimate the welfare loss of the 2003 drought as $€ 91$ million for a certain part of the Rhine market. 
caravans, greenhouses, and especially crops are very vulnerable (van Asseldonk et al. 2001). Moreover, severe hailstorm events may disrupt traffic and increase the probability of car accidents. As a consequence, extreme hailstorms can result in insurance claims for vehicle, property, home furniture, crop/agriculture, casualty, and life/health insurers. A major hailstorm can cause considerable property damage. For example, a severe hailstorm in 1998 caused damage of approximately $€ 100$ million in the Netherlands.

Some studies suggest that a strong positive correlation exists between hailstorm damage and minimum temperature as an approximate storm predictor in France and Switzerland (Dessens 1995; Willemse 1995). These results suggest that a rise in minimum temperatures due to global warming may increase insured hailstorm damage. Results of Dessens (1995) indicate that hailstorm damage increases with about $40 \%$ when the mean minimum temperature increases with $1^{\circ} \mathrm{C}$, using French insured crop damage and temperature data between 1946 and 1992. Botzen et al. (2009b) estimate the relation between a range of monthly indicators of temperature as well as precipitation and agricultural hailstorm damage for the Netherlands in different seasons, using insurance claims between 1990 and 2006. Separate models are estimated for hailstorm damage on outdoor farming and greenhouse horticulture. Results obtained with Tobit models indicate that climate change may increase hailstorm damage considerably, especially during the summer. In particular, estimates made under the KNMI climate change scenarios (Table 2) indicate that hailstorm damage on outdoor farming may increase in between 21 and 55\% for the year 2050 and hailstorm damage on greenhouse horticulture may increase in between 76 and $223 \%$.

Hailstorm damage is to a large extent influenced by changes in societal factors (Changnon 2001). Damages are, for example, influenced by the amount of crops and number of greenhouses and their vulnerability. Insurers in cooperation with the agricultural sector could explore adaptation options that mitigate damage and are effective in terms of costs and benefits. An advantage of the undertaking of such measures is that the reduced risk will be beneficial both to the insurance companies and the farmers. Examples of mitigation measures that could be effective in limiting hailstorm damage on the farming sector are the placement of stronger glass or plastic in greenhouses and the protection of field crops with hail nets. Farmers may also adapt to larger damage expectations after consecutive experiences of large hailstorm damage, by switching to crops or agricultural modes that are less vulnerable to hailstorms.

\subsection{Summary of current risk sharing arrangements for weather risks}

The analysis provided in this section is summarized in Table 3. It shows that a considerable proportion of the main climate risk categories is covered by private insurance companies. In particular, the effects of increased risks of extreme precipitation and flood damage to cars can be substantial. Further, insurers cover a large part of windstorm and hailstorm damage, which may be affected by climate change even though this is still uncertain. The major climate change related risk for the Netherlands is damage due to the collapse of dikes, due to either peak river discharges or storm surge levels. This is the largest threat in terms of potential damages, although probabilities are relatively low. This risk is currently carried by the government via the Calamities and Compensation Act (WTS). This arrangement does, however, not provide a right to compensation. Drought is another major risk for which no risk sharing arrangement is available. It should be noted that households and businesses would also face increasing climate losses apart from possible premium increases, due to deductibles and limitations on coverage. 
Table 3 Current risk sharing arrangements of the main weather risk in the Netherlands

\begin{tabular}{|c|c|c|c|c|}
\hline Weather event & $\begin{array}{l}\text { Climate } \\
\text { change }\end{array}$ & $\begin{array}{l}\text { Potential } \\
\text { damage }\end{array}$ & $\begin{array}{l}\text { Main damage } \\
\text { category }\end{array}$ & Risk sharing arrangement \\
\hline River flood & Increase in risk & $\begin{array}{l}\text { Large-very } \\
\text { large }\end{array}$ & $\begin{array}{l}\text { Motor vehicles } \\
\text { Other property }\end{array}$ & $\begin{array}{l}\text { Private insurance } \\
\text { Government (WTS) }\end{array}$ \\
\hline Storm surge & Increase in risk & Very large & Property & None \\
\hline \multirow[t]{2}{*}{$\begin{array}{l}\text { Extreme } \\
\text { precipitation }\end{array}$} & Increase in risk & Large & $\begin{array}{l}\text { Property households } \\
\text { Property businesses }\end{array}$ & $\begin{array}{l}\text { Private insurance } \\
\text { Limited private } \\
\text { insurance }\end{array}$ \\
\hline & & & Crop losses & $\begin{array}{l}\text { Public-private } \\
\text { partnership }\end{array}$ \\
\hline Windstorm & Uncertain & $\begin{array}{l}\text { Large-very } \\
\text { large }\end{array}$ & $\begin{array}{l}\text { Motor vehicles } \\
\text { Property households } \\
\text { Property businesses }\end{array}$ & $\begin{array}{l}\text { Private insurance } \\
\text { Private insurance } \\
\text { Private insurance }\end{array}$ \\
\hline Extreme drought & Increase in risk & Medium-large & $\begin{array}{l}\text { Crop losses } \\
\text { Waterway transport }\end{array}$ & $\begin{array}{l}\text { None } \\
\text { None }\end{array}$ \\
\hline Hailstorm & Uncertain & Medium-large & $\begin{array}{l}\text { Crop losses } \\
\text { Motor vehicles } \\
\text { Property households } \\
\text { Property businesses }\end{array}$ & $\begin{array}{l}\text { Private insurance } \\
\text { Private insurance } \\
\text { Private insurance } \\
\text { Private insurance }\end{array}$ \\
\hline
\end{tabular}

The analysis so far has focused on possible increases in exposures due to climate change. But climate change can also have positive effects for the Dutch insurance sector. The probability of temperatures below zero is projected to decrease in the Netherlands. This may decrease frost damage to crops. As a result, claims from the agricultural sector can be expected to decrease since coverage of frost damage in certain time periods is included in some crop insurance policies, such as for potatoes, corn and beet farming.

There may be adverse consequences for the insurance sector in case the probability of rain at temperatures close to freezing increases, as this will increase the probability of ice storms, which occur when precipitation falls as rain and freezes upon contact with the earth. Ice storms have adverse economic consequences, for example, because they increase the likelihood of car accidents due to slippery roads. This augments losses for insurance companies that are active in the vehicle insurance market. Moreover, frost and ice storm losses due to business interruption for the transport sector are insured in the Netherlands. Ice storms can also impose significant damage on crops. It is not clear, though, whether this scenario is likely to occur in the Netherlands. The number of days with temperatures below zero is expected to decrease, while winter precipitation is expected to increase.

\section{Possible responses by the insurance industry to climate change}

The previous section has identified extreme weather events that may increase in frequency and severity due to climate change and are covered with insurance policies, such as extreme precipitation, hailstorms and windstorms. Adaptation strategies could limit the increase in risk. However, it is unlikely that adaptation and risk reduction will completely offset the increasing loss trends of natural disasters that have already been observed because of socioeconomic developments (see Sect. 2) and are likely to increase more 
rapidly due to climate change. It can be expected that the insurance sector will face increased weather risk in the future. There are several ways for insurers to respond to increased risks caused by climate change. Insurers can use four main traditional strategies to manage their exposure to natural hazards, namely insurers can limit their risk, adjust premiums, control the damage, and transfer the risk (e.g., Dlugolecki 2000).

Insurers limit their risk by restricting payouts through upper and lower limits (deductibles) of liability or by imposing restrictions and exceptions in insurance contracts. For example, several restrictions and exceptions are included in insurance contracts that cover damage caused by extreme precipitation in the Netherlands. Insurers can further limit their exposure by not providing insurance against certain risks. For instance, Dutch insurance companies exclude coverage against damage caused by flooding. These measures transfer risks to businesses and households and increase pressure on governments to invest in flood prevention, and provide compensation if necessary (Botzen and van den Bergh 2008). Excluding or limiting coverage may be regarded as undesirable since it decreases financial security of households, which lowers welfare of risk averse individuals. Increasing premiums is another strategy to deal with increased risks, which is commonly used after a major catastrophe event (e.g., Kunreuther et al. 2008). A problem with raising premiums is that this often results in public and regulatory resistance and may result in decreased market share if competition is fierce.

Strategies that may not impair the availability and affordability of insurance could be implemented to cope with increased risks as well. Reinsurance-insurance coverage that primary insurance companies buy for their own risk-is commonly used to transfer risk. Another strategy for primary insurers is to diversify risks by operating in various insurance branches or in several geographical areas. Further harmonization of the European financial service market may foster robustness of the insurance sector to climate change by creating a larger geographically spread market. Also, insurance regulation and accounting standards are crucial factors that can support or hinder adaptation to climate change, but that has not been studied in detail yet. The allowance for insurance to efficiently build up sufficient catastrophe reserves to cover disaster losses is a particular example of regulation, which affects the adaptability of the financial sector. Large reinsurers are often better able to handle natural hazard risks as they are better equipped to diversify risks geographically due to operating in large global markets. Limitations of reinsurance are that in certain cases prices are considerably above actuarially fair levels and that coverage obtainable is restricted. This is especially the case after costly catastrophe events, such as major hurricanes in the USA, leading to available capital in reinsurance markets being limited (Kunreuther 2006). High prices of reinsurance may be passed on to consumer via higher premiums. Another option for insurance companies is to hedge risks on capital markets using financial instruments, such as catastrophe bonds, options or futures. Such financial instruments can be used to help acquire funds at times when an insurance company suffers large losses. However, these markets have not adequately developed yet and their use in hedging large weather risks is still limited despite recent growth. These are expected to develop further in the near future (Michel-Kerjan and Morlaye 2008).

Apart from these traditional measures to manage risk, the industry in collaboration with governments could promote long-term policies that limit global warming and its consequences. These greenhouse gas mitigation and adaptation policies may help to maintain the insurability of extreme weather risks. This involves undertaking and stimulating greenhouse gas emission reduction policies, investing in risk assessment research, building public awareness for climate change issues, and promoting adaptation strategies (Mills 1996, 2007; White and Etkin 1997; Mills and Lecomte 2006). This is likely to be a cost- 
effective strategy for insurance companies, given that their exposure to weather risks is significant. The whole insurance sector could benefit from mitigating climate change, implying that there is a rationale for (global) coordinated action. And indeed, insurance companies have since many years been at the forefront of advocating emission reductions.

Several Dutch insurers already have an active climate change policy. For example, Eureko Re offers micro-insurance products in developing countries, which are expected to suffer considerably from climate change impacts. The insurance company Achmea is a member of the Insurance Working Group (IWG) of the United Nations Environmental Programme Finance Initiative (UNEP FI), which stresses climate change-labeled as "the most serious environmental risk facing society" - as a major sustainability issue (UNEP 2007). Moreover, Dutch insurers are investigating to introduce "pay as you drive" insurance policies in cooperation with academics. With such insurance policies, car drivers pay higher insurance premiums when they drive more kilometers. This is expected to result in less driving, which lowers risks of accidents and corresponding insurance claims, while greenhouse gas emissions decrease as well. An assessment of such policies is beyond the scope of this paper. We refer to Mills (2007) for a detailed overview of insurers' responses to climate change around the globe. Interestingly, he finds that most activities within the insurance sector are at the moment focussed on the mitigation of greenhouse gas emissions, rather than adaptation and risk reduction.

Another strategy for insurance companies to reduce weather-related losses is to stimulate adaptation of societies to climate change impacts. This can involve the undertaking of loss-reducing measures at the policy holder level, by rewarding lower risk with lower premiums, higher coverage and lower deductibles (Freeman and Kunreuther 2003). Moreover, providing information about how to reduce vulnerabilities of properties and establishing maximum thresholds of acceptable risks may be effective policies to reduce exposure to weather extremes (Ward et al. 2008). For example, insurers could recommend fire or flood resistant building materials (Thieken et al. 2006). Strategies of promoting costeffective investments by individuals or businesses can be beneficial to both the insurance companies and the insured parties and promote societal adaptation to climate change broadly. However, striking about the findings by Mills (2007) is that most efforts by insurance companies have been targeted at emission reduction and only very few at adaptation.

\section{Conclusions}

The frequency and severity of extreme weather events is likely to increase due to climate change, which is expected to increase insured and other economic losses caused by natural disasters. A considerable rise in damage caused by extreme weather can already be observed in the last decades. This rise in historical insured losses has been mainly caused by socioeconomic developments, such as increases in wealth and economic growth in vulnerable areas. In the future, the combination of societal change and climate change is expected to accelerate upward trends in economic losses due to extreme weather events. The projected rise in damage will have considerable effects on modern societies and the insurance sector in particular.

A thorough understanding of the effects of climate change on the insurance business is important for the sector in order to guarantee adequate pricing of insurance premiums and risk management. Current risk sharing arrangements for major weather risks in the Netherlands have been examined and several adaptation strategies have been suggested in 
this paper. A broad range of insurance arrangements that are affected by climate change can be identified. This requires adequate risk management strategies of insurance companies to handle increased risk. In particular the Dutch insurance sector is very vulnerable to the effects of climate change on extreme precipitation compared with other weather risk. Drought, and large scale flooding which has a smaller probability, have the ability to inflict much large damages but are not insured. Furthermore, insurers have considerable exposure to windstorms and hailstorms but the effects of climate change on the frequency and severity of these events are uncertain. Climate change also brings new business opportunities for the insurance sector, apart from increased exposure to risks under current arrangements. For example, extending crop insurance policies to cover drought damage in the form of a public-private partnership may be a viable arrangement to meet demand for compensation when severe drought periods become more frequent.

Increased exposure to weather risks of insurers indicates the importance of the undertaking of strategies to reduce insurer's vulnerability. This could involve traditional measures, such as limiting risks, raising premiums, transfer damage, or damage control. The first two measures may be undesirable, since they limit insurance availability and merely shift risk to households, businesses and the public sector. One could argue that insurers also have a societal responsibility not only to reduce their own risk but also to serve their clients and help them protect against unbearable financial consequences of major climate risks. Other strategies that reduce risk are also beneficial for insured, in the sense that they limit climate change losses and do not impair insurance availability, involves promotion of emission reduction and adaptation measures in cooperation with public agencies. In addition, insurance companies could stimulate the undertaking of cost-effective riskreducing adaptation measures at the policyholder level. Summarizing, climate change does not only pose challenges for the industry in the face of increasing risks. New business opportunities might emerge and the industry could foster transition toward climate resilient societies.

This paper has examined the possible consequences of climate change for the Dutch insurance sector and provided some indicative estimates of the magnitude of effects. This analysis provides a basis for undertaking future research, which should focus on quantifying the individual climate change effects in more detail. This paper has provided a starting point for prioritizing different hazards and detailing the likelihood that they will change in frequency and severity in the Netherlands. For the purpose of further research, the insurance sector could work together with the academic research community. In particular, insurance companies could contribute detailed historical data on claims of damage caused by extreme weather. Currently, insurers often seem reluctant to share and jointly analyze such insurance claim and loss data, partly because of the competitive value of such data and maybe also because climate change is not considered a research priority by some insurers. These attitudes could change, when the sector recognizes the urgent need to assess their exposure to climate change, and when the projected increases in weatherrelated damage would materialize.

Acknowledgments We thank Jeroen Aerts and André Lucas for helpful comments and Geert Groen (KNMI) and Maarten Heeneman (Dutch Association of Insurers) for providing useful information. This research project was carried out in the context of the Dutch National Research Programme 'Climate Changes Spatial Planning' (http://www.klimaatvoorruimte.nl). The usual disclaimer applies.

Open Access This article is distributed under the terms of the Creative Commons Attribution Noncommercial License which permits any noncommercial use, distribution, and reproduction in any medium, provided the original author(s) and source are credited. 


\section{References}

Aerts JCJH, Bannink B, Sproing TA (eds) (2008) Aandacht voor Veiligheid. http://www.adaptation.nl. IVM Report. Vrije Universiteit, Amsterdam

Berz GA (1999) Catastrophes and climate change: concerns and possible countermeasures of the insurance industry. Mitig Adapt Strateg Glob Change 4:283-293. doi:10.1023/A:1009663605118

Botzen WJW, van den Bergh JCJM (2008) Insurance against climate change and flooding in the Netherlands: present, future and comparison with other countries. Risk Anal 28(2):413-426. doi:10.1111/ j.1539-6924.2008.01035.x

Botzen WJW, van den Bergh JCJM (2009) Bounded rationality, climate risks and insurance: is there a market for natural disasters? Land Econ 85(2):265-278

Botzen WJW, Aerts JCJH, van den Bergh JCJM (2009a) Willingness of homeowners to mitigate climate risk through insurance. Ecol Econ. doi:10.1016/j.ecolecon.2009.02.019

Botzen WJW, Bouwer LM, van den Bergh JCJM (2009b). Climate change and hailstorm damage: empirical evidence and implications for agriculture and insurance (Submitted)

Bouwer LM, Vellinga P (2007) On the flood risk in the Netherlands. In: Begum S, Stive MJF, Hall JW (eds) Flood risk management in Europe: innovation in policy and practice. Springer Verlag, Berlin, pp 469-484

Bouwer LM, Crompton RP, Faust E, Höppe P, Pielke RA Jr (2007) Confronting disaster losses. Science 318:753. doi: $10.1126 /$ science. 1149628

Brouwer R, Akter S, Brander L, Haque E (2007) Socioeconomic vulnerability and adaptation to environmental risk: a case study of climate change and flooding in Bangladesh. Risk Anal 27(2):313-326. doi: 10.1111/j.1539-6924.2007.00884.x

Changnon SA (2001) Damaging thunderstorm activity in the United States. Bull Am Meteorol Soc 82(4):597-608. doi:10.1175/1520-0477(2001)082<0597:DTAITU >2.3.CO;2

Changnon SA (2003) Shifting economic impacts from weather extremes in the United States: a result of societal changes, not global warming. Nat Hazards 29:273-290. doi:10.1023/A:1023642131794

Changnon SA, Pielke RA, Changnon D, Sylves RT, Pulwarty R (2000) Human factors explain the increased losses from weather and climate extremes. Bull Am Meteorol Soc 81:437-482. doi:10.1175/15200477(2000)081<0437:HFETIL>2.3.CO;2

Crompton RP, McAneney KJ (2008) Normalised Australian insured losses from meteorological hazards: 1967-2006. Environ Sci Policy 11(5):371-378. doi:10.1016/j.envsci.2008.01.005

de Rooij A, van den Bergh JCJM (2005) Stilte voor de storm: Verzekeren tegen klimaatverandering. ESB, 17 juni 2005, jaargang 90 nr. 44463

de Sherbinin A, Schiller A, Pulsipher A (2007) Three cities and their vulnerabilities to climate hazards. Mag Int Hum Dimens Programme Glob Environ Chang 2:5-7

Dessens JD (1995) Severe convective weather in the context of a nighttime global warming. Geophys Res Lett 22(10):1241-1244. doi:10.1029/95GL00952

Dlugolecki AF (2000) Climate change and the insurance industry. Geneva Pap Risk Insur 25(4):582-601

Dlugolecki AF (2006) Thoughts about the impact of climate change on insurance claims. In: Höppe P, Pielke RA Jr (eds) Workshop on climate change and disaster losses. Hohenkammer, Germany

Dorland C, Tol RSJ, Palutikof JP (1999) Vulnerability of the Netherlands and Northwest Europe to storm damage under climate change: a model approach based on storm damage in the Netherlands. Clim Chang 43:513-535. doi:10.1023/A:1005492126814

Epstein PR, McCarty JJ (2004) Assessing climate stability. Bull Am Meteorol Soc 85(12):1863-1870. doi: 10.1175/BAMS-85-12-1863

Freeman PK, Kunreuther H (2003) Managing environmental risk through insurance. In: Folmer H, Tietenberg T (eds) The international yearbook of environmental and resource economics 2003/2004. Edward Elgar Publishing, Northampton

Goklany IM (2007). Death and death rates due to extreme weather events: global and US trends, 1900-2004. In: The civil society report on climate change, International Policy Press, London

Groen G (2007) Extreme Zomerneerslag 2006 en Klimaatscenario's. KNMI scientfic report 215. Koninklijk Nederlands Meteorologisch Instituut, De Bilt

Heerkens R (2003) Inventarisatie van de Verzekerbaarheid van Schade als Gevolg van Extreme Regenval en Wateroverlast. Ministerie van Verkeer en Waterstaat RIZA. Werkdocument 2003.219X

Hoff H, Bouwer LM, Berz GA, Kron W, Loster T (2003) Risk management in water and climate: the role of insurance and other financial services. Dialogue on Water and Climate/Munich Reinsurance Company, Delft/Munich

Hoff H, Warner K, Bouwer LM (2005) The role of financial services in climate adaptation in developing countries. Vierteljahrshefte zur Wirtschaftsforschung 74(2):196-207 
IFRC (2003) World disasters report 2002: focus on reducing risk. International Federation of Red Cross and Red Crescent Societies, Geneva

IHDP (2007) The implications of global environmental change for human security in coastal urban areas. Mag Int Hum Dimens Programme Glob Environ Chang, 2 Oct 2007

IPCC (2007) Climate change 2007: the physical science basis. In: Solomon S, Qin D, Manning M, Chen Z, Marquis M, Averyt KB, Tignor M, Miller HL (eds) Contribution of Working Group I to the Fourth Assessment Report of the Intergovernmental Panel on Climate Change. Cambridge University Press, Cambridge

Jonkeren O, Rietveld P, van Ommeren J (2007) Climate change and inland waterway transport, welfare effects of low water levels on the river Rhine. J Transp Econ Policy 41(3):387-411

Jonkman SN, Cappendijk P (2006) Veiligheid Nederland in Kaart: inschatting van het aantal slachtoffers ten gevolge van overstroming. DWW report DWW-2006-012

Kabat P, van Vierssen W, Veraart J, Vellinga P, Aerts J (2005) Climate proofing the Netherlands. Nature 438(7066):283-284. doi:10.1038/438283a

Koetse MJ, Rietveld P (2009) The impacts of climate change and weather on transport: an overview of empirical findings. Transp Res Part D 14(3):205-221

Kok M (2006) Schade na een overstroming: taak van de overheid of eigen verantwoordelijkheid? Externe veiligheid 4:15-17

Kok M, Barendregt A (2004) Verantwoordelijkheid en Aansprakelijkheid bij Wateroverlastschade. Directoraat Generaal Water, HKV Lijn in Water

Kok M, van Gelder PHAJM, Vrijling JK, Vogelsang MP (2002) Risk of flooding and insurance in the Netherlands. In: Wu B et al (eds) Flood defence. Science Press, New York

Kunreuther HC (2006) Has the time come for comprehensive natural disaster insurance? In: Daniels RJ, Kettl DF, Kunreuther HC (eds) On risk and disaster: lessons from Hurricane Katrina. University of Pennsylvania Press, Philadelphia

Kunreuther HC, Michel-Kerjan EO (2007) Climate change, insurability of large-scale disasters and the emerging liability challenge. Univ PA Law Rev 155(6):1795-1842

Kunreuther HC, Pauly M (2006) Rules rather than discretion: lessons from Hurricane Katrina. J Risk Uncertain 33:101-116. doi:10.1007/s11166-006-0173-x

Kunreuther HC, Michel-Kerjan EO, Doherty NA, Grace MF, Klein RW, Pauly MV (2008) Managing largescale risks in a new era of catastrophes: insuring, mitigating and financing recovery from natural disasters in the United States. Wharton Risk Management and Decision Processes Center, Georgia State University, and the Insurance Information Institute, Philadelphia

Michel-Kerjan E, Morlaye F (2008) Extreme events, global warming, and insurance-linked securities: how to trigger the "tipping point". Geneva Pap Risk Insur Issues Pract 33:153-176

Middelkoop H, Daamen K, Gellens D, Grabs W, Kwadijk JCJ, Lang H, Parmet BWAH, Schädler B, Schulla J, Wilke K (2001) Impact of climate change on hydrological regimes and water resources management in the Rhine basin. Clim Chang 49(2-3):105-128. doi:10.1023/A:1010784727448

Miller S, Muir-Wood R, Boissonnade A (2008) An exploration of trends in normalized weather-related catastrophe losses. In: Diaz HF, Murnane RJ (eds) Climate extremes and society. Cambridge University Press, Cambridge, pp 225-347

Mills E (1996) Energy efficiency: no-regrets climate change insurance for the insurance industry. J Soc Insur Res 9(3):21-58

Mills E (2005) Insurance in a climate of change. Science 309:1040-1044. doi:10.1126/science.1112121

Mills E (2007) From risk to opportunity: insurers responses to climate change. Ceres Report, Oct 2007

Mills E, Lecomte E (2006) From risk to opportunity: how insurers can proactively and profitably manage climate change. Ceres Report. Aug 2006

Mills E, Lecomte E, Peara A (2002) Insurers in the greenhouse. J Insur Regul 21(1):43-78

Munich Re (1993) Winter storms in Europe: analysis of 1990 losses and future loss potential. Report 2042E-e. Munich Reinsurance Group, Munich

Munich Re (2002) Topic. Annual review: natural catastrophes 2002. Munich Reinsurance Group, Munich

Munich Re (2005) Claims management following natural catastrophes: experience, analysis, action plans. Munich Reinsurance Group, Munich

Munich Re (2006) Topics geo-annual review natural catastrophes 2005. Munich Reinsurance Group, Munich

Netherlands Environmental Assessment Agency (2005) The effects of climate change in the Netherlands. MNP Report 773001037. MNP, KNMI, RWS-RIZA, RWS, RIKZ, Alterra, IVM ICIS, Bilthoven

Nielen-Kiezebrink MF, Bennink-Heinen CA, Groen M, Meursing L, van Reeken HNM, Rommel MC (2005) Risicobeheersing in Kustplaatsen: beheersing van Kansen en Gevolgen van Kustafslag en Overstromig 
tijdens Zware Storm in Buitendijks Gebied. Raport RIKZ/2005.022. Ministerie van Verkeer en Waterstaat, Den Haag

Pielke RA (2005) Are there trends in hurricane destruction? Nature 438:E11. doi:10.1038/nature04426

Pielke RA, Agrawala S, Bouwer LM, Burton I, Changnon S, Glantz MH, Hooke WH, Klein RJT, Kunkel K, Mileti D, Sarewitz D, Thompkins EL, Stehr N, von Storch H (2005) Clarifying the attribution of recent disaster losses: a response to Epstein and McCarthy. Bull Am Meteorol Soc 86(10):1481-1483. doi: 10.1175/BAMS-86-10-1481

Pielke RA, Prins G, Rayner S, Sarewitz D (2007) Lifting the taboo on adaptation. Nature 445:597-598. doi: $10.1038 / 445597 \mathrm{a}$

Pielke RA, Gratz J, Landsea CW, Collins D, Suanders MA, Musulin R (2008) Normalized hurricane damage in the United States: 1900-2005. Nat Hazards Rev 9(1):29-42. doi:10.1061/(ASCE)1527-6988 (2008)9:1(29)

RIZA, HKV, Arcadis, KIWA, Korbee \& Hovelunck, Klopstra D, Versteeg R, Kroon T (2005) Droogtestudie Nederland: Aard, Ernst en Omvang van Watertekorten in Nederland. RIZA rapport 2005.016

Sanchez-Rodriguez R, Pacyna J, O’Brien K, Fragkias M, Rosentrater L, Weichselgartner J (2007) Introduction to the "global environmental change, natural disasters, vulnerability and their implications for human security in coastal urban areas" issue. Mag Int Hum Dimens Programme Glob Environ Chang 2:4-5

Stern N (2007) The economics of climate change: the stern review. Cambridge University Press, Cambridge

Stuyt LCPM, van Bakel PJT, Kroes JG, Bos EJ, van der Elst M, Pronk B, Rijk PJ, Clevering OA, Dekking AJG, van der Voort MPJ, de Wolf M, Brandenburg WA (2006) Transitie en Toekomst van Deltalandbouw: Indicatoren voor de Ontwikkeling van de Land- en Tuinbouw in de Zuidwestelijke Delta van Nederland. Alterra-Rapport 1132. Alterra, Wageningen

Swiss Re (2003) Natural catastrophes and man-made disasters 2003: high flood loss burden. Sigma Report 2/2003. Swiss Re Reinsurance Company, Zurich

Swiss Re (2005) Natural catastrophes and man-made disasters in 2004: more than 300000 fatalities, record in insured losses. Sigma Report 1/2005. Swiss Re Reinsurance Company, Zurich

Swiss Re (2006) Natural catastrophes and man-made disasters 2005: high earthquake casualties, new dimension in windstorm losses. Sigma Report 2/2006. Swiss Re Reinsurance Company, Zurich

Thieken AH, Petrow T, Kreibich H, Merz B (2006) Insurability and mitigation of flood losses in private households in Germany. Risk Anal 26(2):383-395. doi:10.1111/j.1539-6924.2006.00741.x

Tol RSJ (2002a) New estimates of the damage costs of climate change, part I: benchmark estimates. Environ Resour Econ 21(1):47-73. doi:10.1023/A:1014500930521

Tol RSJ (2002b) New estimates of the damage costs of climate change, part II: dynamic estimates. Environ Resour Econ 21(2):135-160. doi:10.1023/A:1014539414591

Tucker M (1997) Climate change and the insurance industry: the cost of increased risk and the impetus for action. Ecol Econ 22:85-96. doi:10.1016/S0921-8009(96)00556-3

UNEP (2007) Insuring for sustainability: why and how the leaders are doing it. The inaugural report of the Insurance Working Group of the United Nations Environmental Programme Finance Initiative. 2007 Report. UNEP Finance Initiative, Switzerland

van Asseldonk MAPM, Meuwissen MPM, Huirne RBM (2001) Stochastic simulation of catastrophic hail and windstorm indemnities in the Dutch greenhouse sector. Risk Anal 4:761-769. doi:10.1111/02724332.214148

van den Hurk B, Tank AK, Lenderink G, van Ulden A, van Oldenborgh GJ, Katsman C, van den Brink H, Keller F, Bessembinder J, Burgers G, Komen G, Hazeleger W, Drijfhout S (2006) KNMI climate change scenarios 2006 for the Netherlands. KNMI scientific report WR 2006-01

van der Meer RW, van Asseldonk MAPM, van der Meulen H (2007) Klimaat voor Verzekeren? Oogstschade Verzekering in de Akkerbouw. Rapport 6.07.07. Landbouw Economisch Instituut (LEI), Den Haag

van der Meulen H, van Asseldonk M, Buurma J, Nienhuis J (2006) Mogelijkheden tot een Brede Weersverzekering. Rapport 6.06.15. LEI, Den Haag

van Schoubroeck C (1997) Legislation and practice concerning natural disasters and insurance in a number of European countries. Geneva Pap Risk Insur Issues Pract 83:238-267

Vellinga P, Mills E, Berz G, Bouwer LM, Huq S, Kozak LA, Palutikof J, Schanzenbächer B, Soler G (2001) Insurance and other financial services, Chap. 8. In: McCarthy JJ, Canziani OF, Leary NA, Dokken DJ, White KS (eds) Climate change 2001: impacts, adaptation, and vulnerability. Cambridge University Press, Cambridge, pp 417-450

Verbeek K (ed) (2003) De Toestand van het Klimaat in Nederland 2003. Royal Dutch Meteorological Institute, De Bilt 
Versteeg R, Klopstra D, Kroon T (2005) Droogtestudie Nederland. RIZA, HKV, Arcadis, KIWA, Korbee, Hovelynck. RIZA-rapport 2005.015

Ward RET, Herweijer C, Patmore N, Muir-Wood R (2008) The role of insurers in promoting adaptation to the impacts of climate change. Geneva Pap Risk Insur Issues Pract 33:133-139

White R, Etkin D (1997) Climate change, extreme events and the Canadian insurance industry. Nat Hazards 16(2-3):135-163. doi:10.1023/A:1007934511961

Wijngaard JB, Kok M, Smits I, Talsma M (2005) Nieuwe statistiek voor extreme neerslag. H2O 6:35-37

Willemse S (1995) A statistical analysis and climatological interpretation of hailstorms in Switzerland. Doctor of Natural Sciences Thesis Dissertation No. 11137. Swiss Federal Institute of Technology, Zurich, p. 176 